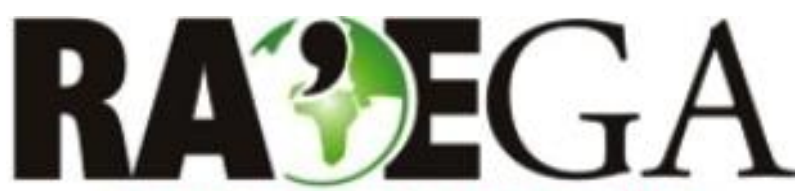

O ESPAÇO GEOGRÁFICO EM ANÁLISE

\title{
HYDROLOGICAL DYNAMICS AND RURAL MOBILITY: CONSIDERATIONS ON THE CATTLE TRANSIT IN THE SOUTH PANTANAL IN YEARS OF EXTREME EVENTS: THE DROUGHT OF 2010 AND THE FLOOD OF 2014
}

\section{DINÂMICA HIDROLÓGICA E MOBILIDADE RURAL: CONSIDERAÇÕES SOBRE O TRÂNSITO DE BOVINOS NO PANTANAL SUL EM ANOS DE EVENTOS HIDROLÓGICOS EXTREMOS: A SECA DE 2010 E A INUNDAÇÃO DE 2014}

Ana Gabriela de Jesus Araujo ${ }^{1}$, Débora Luisa Silva Teixeira², Luan Moreira Grilo³ ${ }^{3}$ Luiz Tadeu da Silva ${ }^{4}$, Gilvan Sampaio de Oliveira ${ }^{5}$, Antônio Miguel Vieira Monteiro ${ }^{6}$, Guillermo O. Obregón Párraga ${ }^{7}$, Mônica Tatiane Souza ${ }^{8}$

\begin{abstract}
The Pantanal is one of the largest wetlands in the world. In Mato Grosso do Sul, the floodplain stands out on the calf production by the use of native grasslands as pastures. It has as a management characteristic the movement of the herds between lowlands and higher areas, at the pace of the annual floods. The commercialization of cattle for rearing, fattening or slaughtering with other localities consolidates an'always in motion'livestock farming. Severe hydrometeorological events act as forcings on the management of production, which may impact on increased costs and losses. To contribute to the understanding of the territorial organization of the activity in the region, this study identified the multiannual pattern of cattle traffic at intra and intermunicipal scales and between lowland and plateau areas between 2007 and 2014. In addition, it presented the dynamics of cattle displacement in Aquidauana and Corumbá, municipalities with the largest areas of wetlands and cattle production of the South Pantanal, considering the episodic events of drought in 2010 and full in 2014. The results showed that the flow of cattle presents different levels of connectivity, with emphasis on intra-Pantanal displacement. Increases were observed in the periods of drought and pre-flood and decrease in the flood months; as well as an occasional intense flow in 2014, suggesting an emergency. This endorses adaptive strategies and the need for actions that minimize the impacts of weather and climate variability on cattle breeding in the region.
\end{abstract}

Keywords: Cattle breeding, complex network, hydrology, severe hydrological events.

\section{RESUMO}

O Pantanal é uma das maiores áreas úmidas do mundo. No estado de Mato Grosso do Sul, a planície de inundação se destaca na produção de bezerros e tem como característica de manejo o deslocamento dos rebanhos por entre as terras baixas e altas, ao ritmo das cheias anuais e oferta das pastagens nativas. A comercialização de gado para criação, engorda ou abate com outras localidades consolida uma pecuária "sempre em movimento". Eventos hidrometeorológicos severos atuam como forçantes no gerenciamento da produção, o que pode impactar no aumento de custos e perdas. Para contribuir com a compreensão da organização territorial da atividade na região, este estudo identificou o padrão plurianual do tráfego de gado nas escalas intra e intermunicipal e entre as regiões de planície e planalto entre 2007 e 2014. Além disso, a pesquisa apresentou a dinâmica do deslocamento dos bovinos entre Aquidauana e Corumbá, municípios com as maiores áreas de várzea e produção de gado do Pantanal Sul, considerando os episódios de seca em 2010 e cheias em 2014. Os resultados mostraram que o fluxo de gado apresenta diferentes níveis de conectividade, com ênfase no deslocamento intra-Pantanal. Foi observado o aumento do tráfego nos períodos de seca e pré-inundação e diminuição nos meses de cheia; bem como um intenso fluxo ocasional em 2014, sugerindo uma situação de emergência. Isso endossa as estratégias adaptativas e

\footnotetext{
${ }^{1}$ National Institute for Space Research - INPE, Cachoeira Paulista/SP, email: anaaraujogeo@gmail.com ${ }^{2}$ National Institute for Space Research - INPE, Cachoeira Paulista/SP, email: debora.teixeira@inpe.br ${ }^{3}$ National Institute for Space Research - INPE, Cachoeira Paulista/SP, email: luan.grilo@inpe.br ${ }^{4}$ National Institute for Space Research - INPE, Cachoeira Paulista/SP, email: luiz.tadeu@inpe.br ${ }^{5}$ National Institute for Space Research - INPE, Cachoeira Paulista/SP, email: gilvan.sampaio@inpe.br ${ }^{6}$ National Institute for Space Research - INPE, São José dos Campos/SP, email: miguel@dpi.inpe.br ${ }^{7}$ National Institute for Space Research - INPE, Cachoeira Paulista/SP, email: guillermo.obregon@inpe.br ${ }^{8}$ EngeotecGeotechnology, São José dos Campo/SP, email: monicatatiane@hotmail.com
} 
necessidade de ações que minimizem os impactos da variabilidade climática na pecuária da região.

Palavras chave: Pecuária bovina, redes complexas, hidrologia, eventos hidrológicos severos.

\section{INTRODUCTION}

Brazil has a population of 212.3 million cattle, second only to India. The states of Mato Grosso, Minas Gerais, Goiás, Mato Grosso do Sul and Pará together account for more than half of the national herd (54.1\%) (IBGE, 2015).

In the wetland region of Mato Grosso do Sul, beef cattle breeding is extensive and based on a great variety of native pastures. The activity has as a characteristic the frequent displacement of livestock according to the availability of pastures, which are always renewed with the passage of water (POTT, 1994). To the pattern of annual floods, which also determines the conditions of access and movement, the Pantanal inhabitant builds its territorial strategies for the upkeep of the livestock (ARAUJO et al., 2018; ABREU et al., 2010; SANTOS et al., 2002).

Between 2007 and 2014, 32,163,331 bovines were moved in the region (IAGRO, 2015a), predominantly by truck transport (56.38\%) and on foot (39.37\%). This traditional "nomad" herd handling is preserved until today and reflects a dynamic landscape, "always in movement", being common to find the cattle drives, who take the animal lots, traveling long distances and connecting places in trips that can last months (BERT et al., 2008).

The South Pantanal livestock landscape can be observed in different (but complementary) spatial units, even reaching the comparison between farms. When the municipality represents this spatial unit, particularities can be observed in the execution of the phases of the breeding-rearing-fattening cycle of beef cattle.

Moraes (2008) carried out a sample survey to verify the purpose of the displacement of the herds and confirmed the importance of this practice, either for the management adapted to the pace of the floods on the plains in different farms forming a network, or for commercialization with areas of the plateau. Araujo et al. (2011) mapped several of these "circuits" of articulated farms and found rural properties exclusively for breeding in the wetland; others for rearing and/or fattening, located in both the wetland and the plateau; and others from other regions of Mato Grosso do Sul, which supply the breeding matrices and in return receive calves for the complete breeding-rearingfattening cycle.

The city of Corumbá, for example, is almost entirely located in the lowlands of the floodplain. It has the second largest herd in Brazil (IBGE, 2015) and it stands out in the breeding phase: calf production for delivery to other localities (SANTOS et al., 2005 (SANTOS et al., 2011). On the other hand, border municipalities that also have plateau lands, such as Aquidauana and Coxim, maintain the traditional breeding system in the wetlands. However, in the highlands, the stages of rearing and fattening are performed in a more robust way, making use of planted pastures and a somewhat more technical management and administration. Also, they are closer to the state's refrigeration industry (OLIVEIRA et al., 2016; ARAUJO et al., 2011).

Thus, a region with a certain productive cohesion is formed (ZENITH and SUGAI, 1994). At the same time, it is complemented by the production and commercialization of each phase of cattle, articulating localities with different altitudes, land use and land cover. Aquidauana is situated in the transition to the Maracaju Mountain Range, also possessing plateau areas in the Upper Paraguay Basin (BAP). In a way, it preserves the municipality of the susceptibility to the floods of the Aquidauana river, a stream of very variable profile in the amplitude of annual fluvial levels (ARAUJO et al., 2018). 


\section{HYDROLOGICAL DYNAMICS AND RURAL MOBILITY: CONSIDERATIONS ON THE CATTLE TRANSIT IN THE SOUTH PANTANAL IN YEARS OF EXTREME EVENTS: THE DROUGHT OF 2010 AND THE FLOOD OF 2014}

Compared to Corumbá, the city has a greater intensification of the productive space, with a higher stocking rate (animal/ha), smaller rural properties and greater use of planted pastures, mainly in its plateau lands, including even semi-confinement for the fattening (ARAUJO, 2018). Aquidauana also has a conurbation with the town of Anastácio, which has a large refrigeration industry. This makes Aquidauana a channel for the flow of cattle coming from other places, in the stage of finishing and slaughter.

The Ministry of Agriculture in Brazil oversees the monitoring of the transit of animals. Whatever the means of travel, it is mandatory to have the Animal Transit Guide (GTA), an official document that contains information on origin and destination, the means of transport used, the characteristics of the animals, as well as the purpose of the displacement (BRASIL, 2006).

Regarding hydrology on a multiannual scale, although the Pantanal presented a wetter pattern from the mid-1970s forward (COLLINSCHONN et al., 2001; CLARKE et al., 2003), there were severe drought events, such as in the years 1999, 2005, 2008, 2010 and 2012, interspersed with intense floods, as in 1988, 1995, 2011 and 2014. This dynamic draws attention to the pace of this variability in terms of frequency and intensity and its effects on the daily life and the territories of the Pantanal populations (ECOA, 2014; FERNANDES and DA ANUNCIAÇÃO, 2012; PEREIRA e YULE, 2011; LIMA et al., 2011; SOARES et al., 2010; SOARES et al., 2007).

Likewise, despite negative trends in rainfall and river levels starting in the second half of the 1990s (ARAUJO et al., 2018; TOZATO et al., 2013), it is worth highlighting the spatio-temporal variability of the levels of the rivers that drain the Pantanal Sul, which implies intra-regional differences in the pace of the pulse and localized floods. For example, greater intra-annual variability of rainfall, as in the period 2010-2011, which interrupted a severe and prolonged drought that began in 2009 and affected more significantly to the south and southeast (MORAES et al., 2013; LIMA et al., 2011; SOARES et al., 2010).

Considering the diversity of localized climatic processes and the extensive Pantanal area, new research should strive to work with more refined spatio-temporal scales and combine their results with interest in strategies (institutional or autonomous), flood monitoring and warnings adjusted to periods and subregions (ADÁMOLI, 1986; TUCCI et al., 1995; PADOVANI et al., 2011).

Since cattle transit is a specificity of the management of Pantanal beef cattle (CADAVID GARCIA, 1985), severe hydrological events may result in losses such as, for example, the increase of costs with the nutritional supplementation in years of severe drought or the loss of animals through isolation, hunger and drowning in the case of large floods; interfering with the cattle marketing (FARIAS, 2018; CORREIO DO ESTADO, 2011). Factors such as the compulsory sale or early withdrawal of these animals are therefore required from producers in the face of displacement limitations.

\section{OBJECTIVE}

This work identified the dynamics of cattle displacement in the South Pantanal between 2007 and 2014, based on a matrix of origin/destination elaborated in a geographic information system (GIS), according to the complex territorial networks approach developed by Santos (2014; et al., 2017; et al., 2019 in press). Regarding the cities of Corumbá and Aquidauana, a characterization of the hydrological variables and traffic flows in the intra and intermunicipal scales and between the lowland/plateau areas was also carried out, focusing on the possible associations between the variables in two years representing extreme hydrometeorological events in the region, 2010 (dry) and 2014 (flood). 
ARAUJO, A. G. J., TEIXEIRA, D. L. S., GRILO, L. M., SILVA, L. T., OLIVEIRA, G. S., MONTEIRO, A. M. V., PARRARA, G. O., SOUZA, M. T.

\section{HYDROLOGICAL DYNAMICS AND RURAL MOBILITY: CONSIDERATIONS ON THE CATTLE TRANSIT IN THE SOUTH PANTANAL IN YEARS OF EXTREME EVENTS: THE DROUGHT OF 2010 AND THE FLOOD OF 2014}

\section{METHODOLOGY}

The cattle displacement data were collected through the Animal Care System of the State Agency of Sanitary Monitoring (IAGRO). The SANIAGRO is based on animal transit guides relating to flow control, measured in accordance with Ordinance number 3,505/2015 and Law number 5,741/2006 (IAGRO, 2015a; BRASIL, 2006). These data provided the numbers of animals moved per month, according to the municipality of origin and destination, the intramunicipal subregion (either plain or plateau), breeding purpose and means of transport used.

A GIS database was also constructed, a computational system that allows the integration and manipulation of different geographic information and that represents in maps form the topological elements structure, attributes, and phenomena studied, considering their spatial relations in terms of proximity, contiguity and connectivity (LANG and BLASCHKE, 2009; CÂMARA and MONTEIRO, 2001). In this perspective, the spatial analysis in GIS allows an approximation between the concepts and analytical categories of geography, such as space, region, and territory. The alphanumeric cartographic and thematic data used are presented in the global cartographic projection UTM-Sirgas 2000.

The monthly series of bovine transit were initially compiled and organized in a Microsoft $^{\circledR}$ Access database. The original thematic columns were maintained. The subregions centroids of the plain and plateau of each municipality were extracted, which represent the vertices of the displacement network graphs. The graphs construction (one for each year) had as criterion the existence of the flow between the subregions.

From this origin/destination matrix and according to the approach of complex networks of territorialized base developed by Santos (2014; et al., 2017; et al., 2019 in press), a graph analysis was performed to visualize the networks built by the rural mobility of Pantanal's livestock.
To identify the pattern of hydrological behavior in 2010 and 2014, two fluviometric stations were selected, one in the Aquidauana river (No. 66945000) and another in the Paraguay river (No. 66825000), so that they could represent the flood dynamics in each municipality. Both belong to the National Water Agency (ANA) and their data are available on the ANA's Hidroweb website. The station located in Aquidauana also registers pluviometric measurements, while Corumbá is represented by the rainfall station Nhumirim, belonging to the EMBRAPA Pantanal, which kindly yielded the information.

Specifically, the methodological procedures of this article are data collection; organization and selection of cadastral information in a geographic database; selection of query variables on the database and synthesis in graphs and tables for analysis.

\section{RESULTS AND DISCUSSION}

\subsection{A nomadic cattle breeding}

The dynamic character in the time and space of livestock farming in the South Pantanal stands out. Firstly, for the production articulation: when the flood rhythm modifies the seasonal supply of the pasture areas, determining the periods of use and permanence in the low areas. In this way, with the arrival of the waters, the herd displacement to higher areas occurs either on the same farm or between different properties. Secondly, by specialization in the execution of the production cycle phases, where the environmental character of each rural property is harnessed in terms of either native or planted pastures and technical inputs, optimizing the productive space according to the needs of each herd life stage (breeding, rearing and fattening) (MORAES, 2008; ARAUJO, 2006).

In relation to the territorial logic of the herd management developed at regional scale, the South Pantanal municipalities have strong intra and interregional connections, such as the highlands of the border plateau, as well as a 
ARAUJO, A. G. J., TEIXEIRA, D. L. S., GRILO, L. M., SILVA, L. T., OLIVEIRA, G. S., MONTEIRO, A. M. V., PARRARA, G. O., SOUZA, M. T.

\section{HYDROLOGICAL DYNAMICS AND RURAL MOBILITY: CONSIDERATIONS ON THE CATTLE TRANSIT IN THE SOUTH PANTANAL IN YEARS OF EXTREME EVENTS: THE DROUGHT OF 2010 AND THE FLOOD OF 2014}

flexible and discontinuous territoriality on the local scale, with farms articulated with each other (ARAUJO et al., 2016; ARAUJO, 2006; MORAES, 2008).

In the flow of bovines, it is observed that old ways such as river transport and the displacement on foot in cattle drives are still conducted. Despite the increasing trend of trucking, whether sending to other breeders or in direct sales to the Mato Grosso do Sul slaughterhouses, the "on foot" type of transport is predominant (ARAUJO et al., 2016; D'OLIVEIRA et al., 2014; ROSA et al., 2007).
Taking Corumbá as an example, according to IAGRO records (2015b), 495,995 cattle were moved on foot and 379,676 were displaced by road transport in 2014. During the "on foot" transport, the distances covered reach hundreds of kilometers and can last months. The dynamics of this displacement reveal a dense movement of coming and going that reinforces the fluidity narrative as an adaptive strategy of the Pantanal livestock farming. Figure 1 shows the Pantanal Sul municipalities and explains the proportions of areas of plain and plateau traveled by the "nomadism" of the regional cattle breeding.

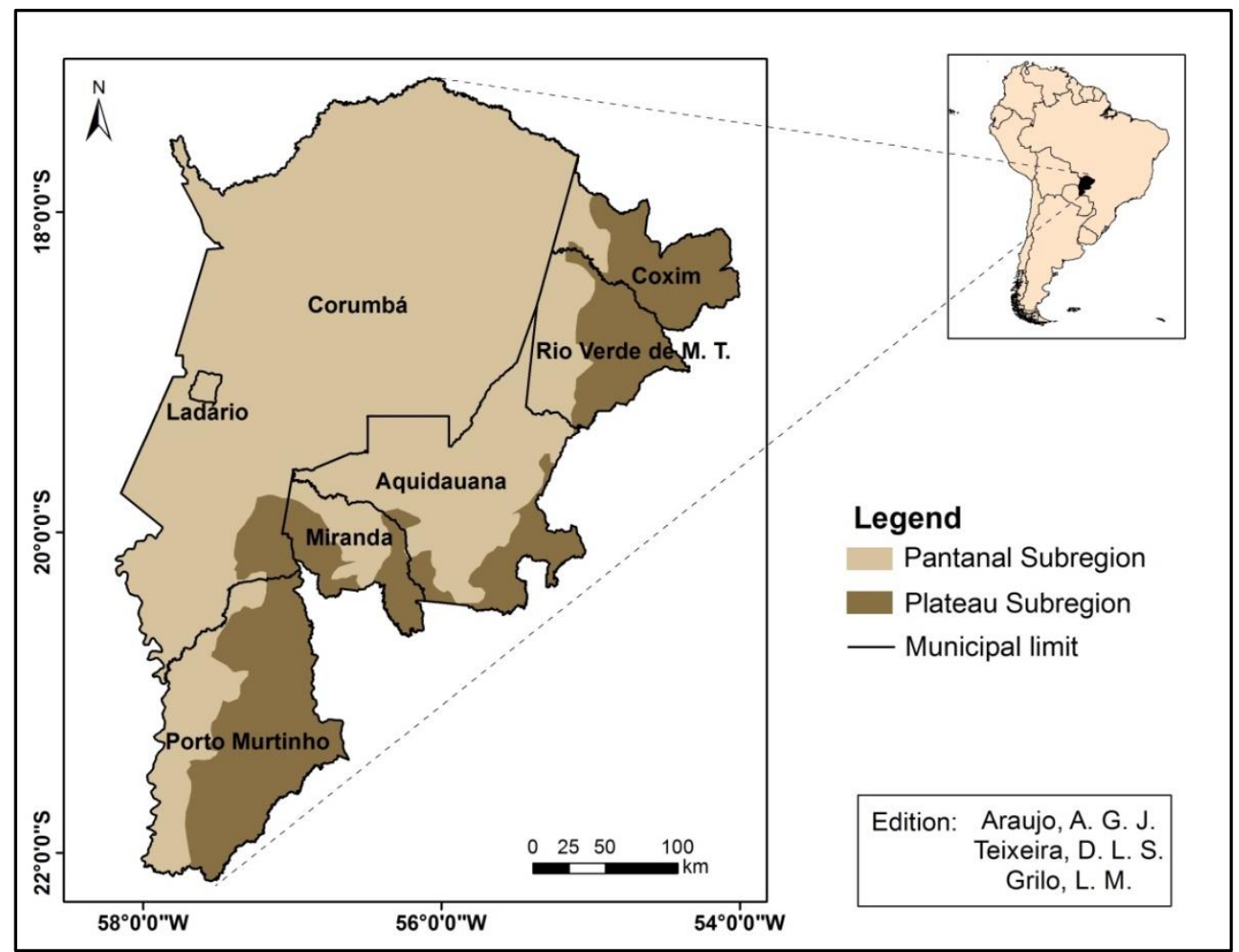

Figure 1 - Municipalities analyzed in the Pantanal Sul. Source: Adapted from Silva and Abdon (1998).

To illustrate mobility as a character of the local cattle breeding, Table 1 shows the destination of the animal flows that left the South Pantanal. It is clearly possible to notice that most remained in the wetlands of the seven municipalities, almost five million and seven hundred thousand cattle. However, approximately $45 \%$ of the total number of animals were moved to the plateau, with the Upper Paraguay Basin (BAP) subregions being the main destination for cattle, with the exception of the municipality of Corumbá. 
Table 1 -Total registered number of cattle displacement between 2007 and 2014 of the Pantanal Sul, according to intra-municipal subregions of destination

\begin{tabular}{|c|c|c|c|c|c|c|}
\hline \multirow[b]{2}{*}{$\begin{array}{l}\text { Municipalitiesofori } \\
\text { gin }\end{array}$} & \multicolumn{4}{|c|}{ Regionsofdestination } & \multirow[b]{2}{*}{ Total } & \multirow[b]{2}{*}{$\%$} \\
\hline & $\begin{array}{c}\text { BAP } \\
\text { Pantanal }\end{array}$ & $\begin{array}{c}\text { BAP } \\
\text { Platau }\end{array}$ & $\begin{array}{l}\text { Paraná } \\
\text { Basin }\end{array}$ & $\begin{array}{c}\text { Outside } \\
\text { Mato } \\
\text { Grosso do } \\
\text { Sul }\end{array}$ & & \\
\hline Corumbá & $3,524,393$ & $2,139,903$ & $\begin{array}{r}344,83 \\
2\end{array}$ & 6,614 & $6,015,742$ & 49.25 \\
\hline Aquidauana & 774,079 & $1,244,141$ & $\begin{array}{r}164,23 \\
1\end{array}$ & 3,384 & $2,185,835$ & 17.90 \\
\hline Porto Murtinho & 553,825 & 632,394 & $\begin{array}{r}166,71 \\
2\end{array}$ & 12,053 & $1,364,984$ & 11.18 \\
\hline Rio Verde de MT & 329,137 & 831,244 & $\begin{array}{r}144,84 \\
9\end{array}$ & 5,630 & $1,310,860$ & 10.73 \\
\hline Coxim & 285,166 & 435,040 & 88,271 & 10,225 & 818,702 & 6.70 \\
\hline Miranda & 175,289 & 261,805 & 14,329 & 2,121 & 453,544 & 3.71 \\
\hline Ladário & 53,707 & 11,237 & 0 & 0 & 64,944 & 0.53 \\
\hline $\begin{array}{c}\text { Tota } \\
\text { I }\end{array}$ & $5,695,596$ & $5,555,764$ & 923,224 & 40,027 & $12,214,611$ & 100 \\
\hline$\%$ & 46.63 & 45.48 & 7.56 & 0.33 & 100 & \\
\hline
\end{tabular}

Source: Araujo (2018).

Considering the "nomadic" management in the region, the interactions between the intramunicipal subregions reveal an expressive displacement. Disregarding the internal traffic of each subregion, the network diagnosis generated in the accumulated graphs between 2007 and 2014 (Figure 2) reveal that the Corumbá subregion was the one that received most cattle in terms of volume, 361,532 , and origins possible, being the main destination of Aquidauana, Ladário, Miranda and Porto Murtinho municipalities. It is worth mentioning that these main emitters are all in the Pantanal subregions of the four municipalities.

In second and third place, the subregions that received most bovines in the period were, respectively, the Pantanal of Miranda, which represented the main destination of cattle displaced from Corumbá and received a total of 277,816 animals; and the plateau of Rio Verde de Mato Grosso, destination of 81,056 bovines from Coxim plateau areas. 


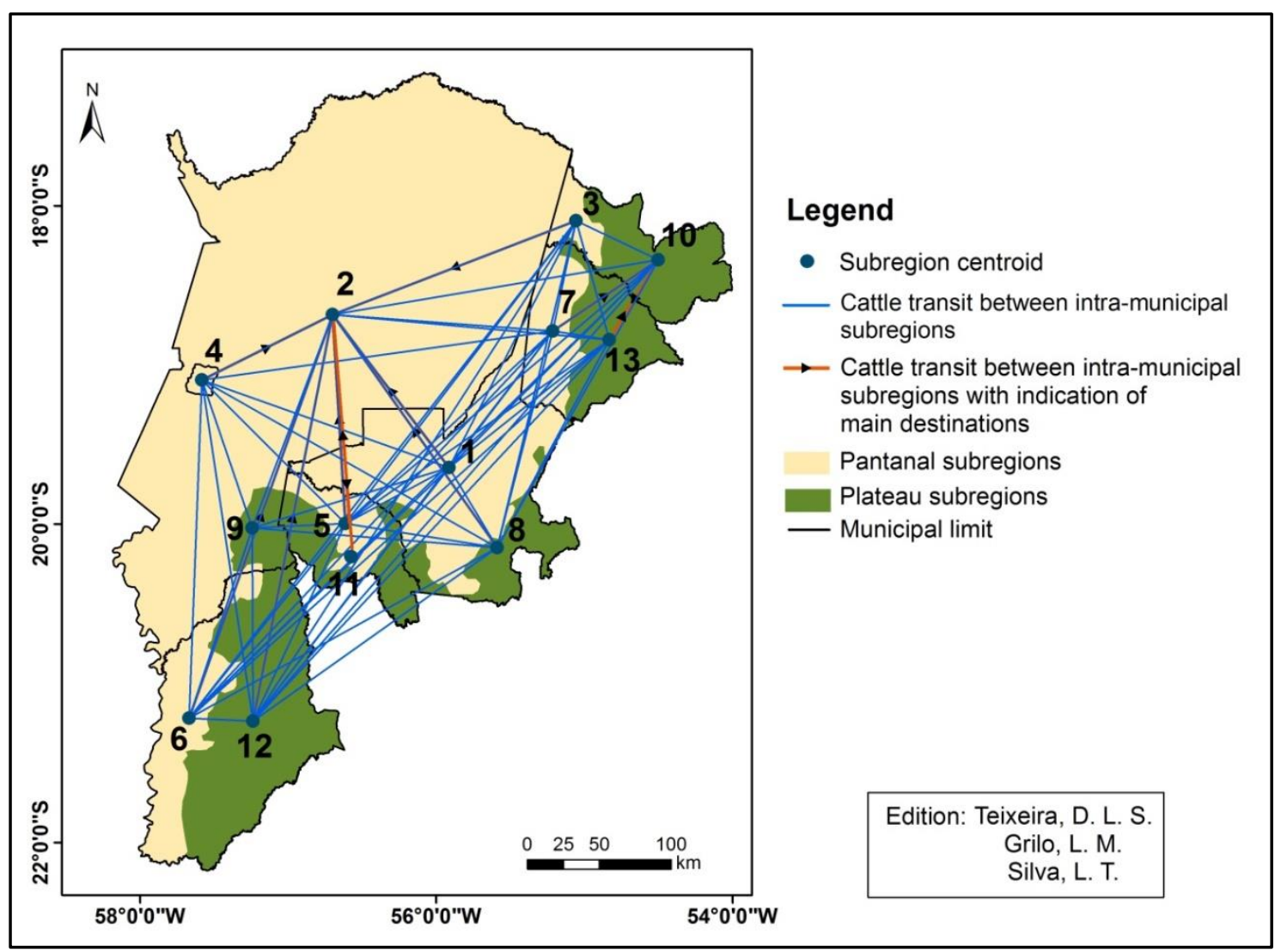

Figure 2 - Graph of accumulated cattle flows between the intra-municipal subregions of the South Pantanal between 2007 and 2014. The numbering of 1 to 7 corresponds to the sub-regions of wetlands of: 1) Aquidauana; 2) Corumbá; 3) Cushion; 4) Ladário; 5) Miranda; 6) Porto Murtinho; and 7) Rio Verde de Mato Grosso. The numbering from 8 to 13 corresponds to the plateau subregions: 8) Aquidauana; 9) Corumbá; 10) Coxim; 12) Miranda; 13) Porto Murtinho; and 14) Rio Verde de Mato Grosso. There was no flow to/from the Ladario plateau subregion in the seven-year period.

Source: IAGRO (2015a), compiled and organized by the authors.

\subsection{Recent severe hydrological events in Pantanal}

The mobility observation results from the herd with the hydrometeorological dynamic will be presented ahead, assuming them as two cartographic representations of productive territorial dynamics that must be integrally observed.

\subsection{The 2010 drought}

Figure 3 presents the rain anomalies related to the climatological normals (INMET, 2009). The below average precipitation constant is identified all over the year in the cities of Corumbá and Aquidauana, with exception in spring and the beginning of summer from September to January. 
ARAUJO, A. G. J., TEIXEIRA, D. L. S., GRILO, L. M., SILVA, L. T., OLIVEIRA, G. S., MONTEIRO, A. M. V., PARRARA, G. O., SOUZA, M. T.

HYDROLOGICAL DYNAMICS AND RURAL MOBILITY: CONSIDERATIONS ON THE CATTLE TRANSIT IN THE SOUTH PANTANAL IN YEARS OF EXTREME EVENTS: THE DROUGHT OF 2010 AND THE FLOOD OF 2014

a)

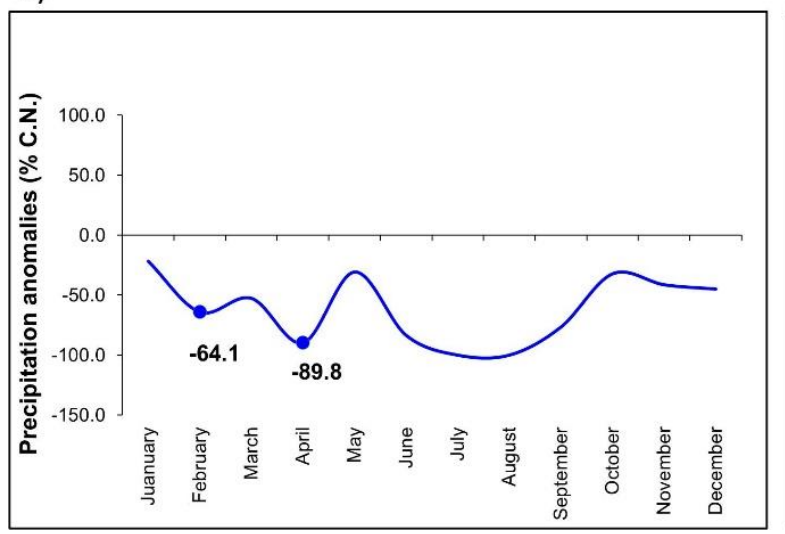

b)

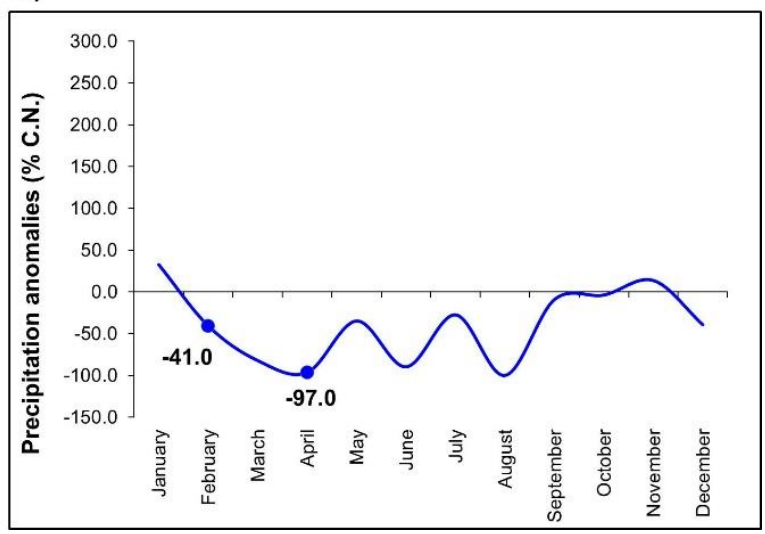

Figure 3 -Precipitation anomalies (\%) from Corumbá (a) and Aquidauna (b) in 2010. Source: adapted from Araujo (2018).

Complementary to Figure 4, the hydrological behavior from both Paraguay and Aquidauana rivers contribute for the cities flooding dynamic. The registered low rain volume is reflected in the Aquidauana river levels behavior, despite the elevated high and low amplitude frequency registration, which is almost nullified in the second semester of the year, mainly in august, which shows low variability and $270 \mathrm{~cm}$ levels. a)

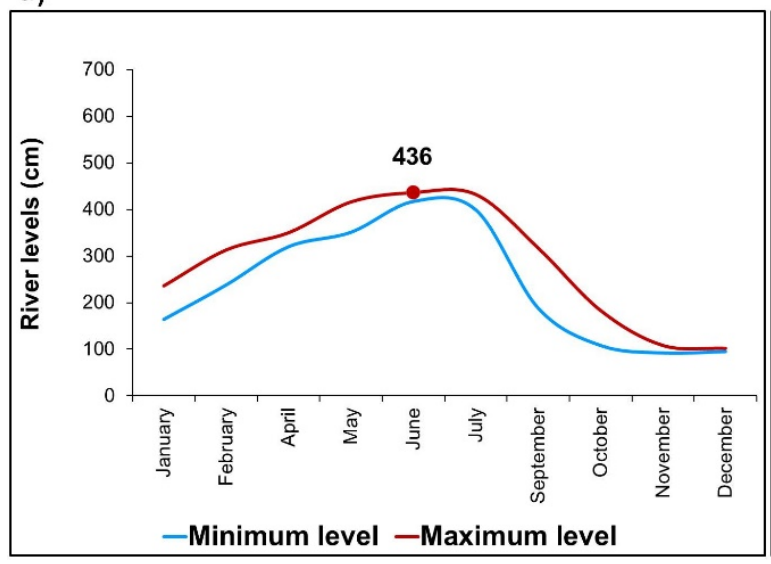

b)

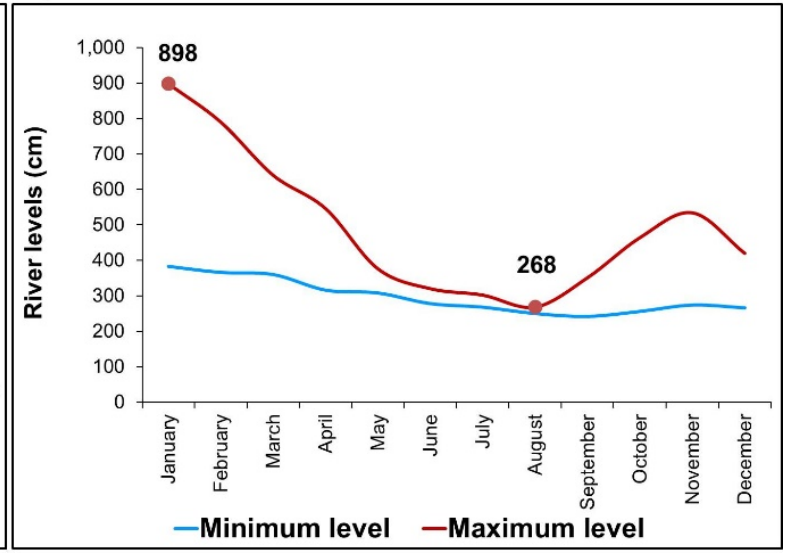

Figure 4. Paraguay (a) and Aquidauana (b) rivers levels (cm) in 2010.

Source: adapted from Araujo (2018)

Connecting the hydrological dynamic with the monthly cattle displacement in 2010 (Figure 5a), it is possible to observe that Corumbá showed its maximum in March, June and December, alongside with the influx of eighty thousand animals in March and December and of almost seventy thousand in June, the most severe drought month of 2010. The same is observed in Aquidauana, which had an increase of animal influx in March, possibly due to the beginning of the ebb (downstream water flow), which renovates the lowest areas pasture, providing additional food for the cattle. 
a)

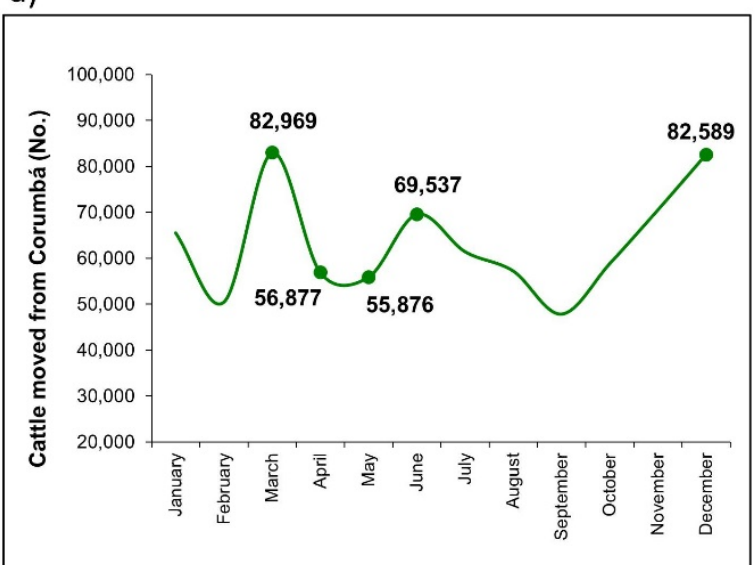

b)

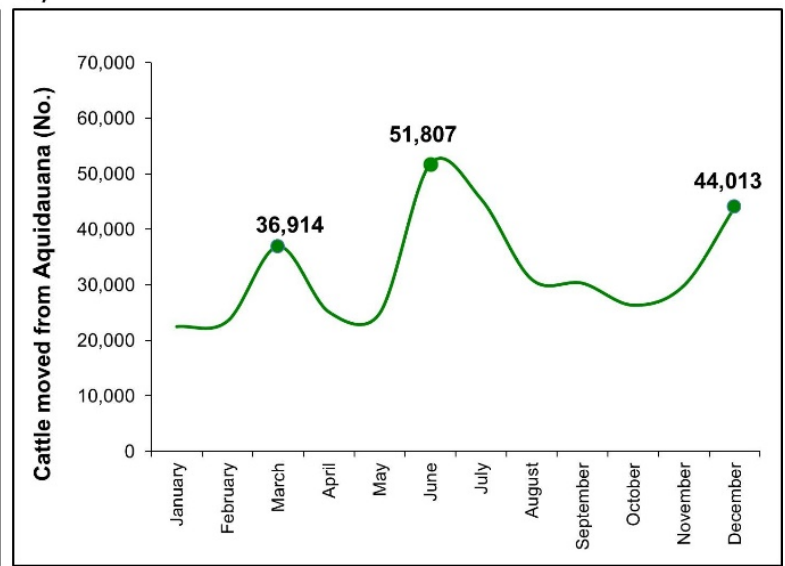

Figure 5 -The total cattle displacement of 2010 from Corumbá (a) and from Aquidauana (b). Source: Adapted from Araujo (2018).

However, in June, in the beginning of the drought in the Aquidauana river, it occurred the biggest cattle displacement, around 51,807 bovines, which could express a prevention measure taken by the ranchers due to the low quality and the shortage of pasture for Aquidauana's herd (Figure 5b).

\subsection{Flood}

2014 has shown a rain behavior and river level response that triggered an extreme flood in South Pantanal, being the south and southeast plains the most affected regions. According to EMBRAPA Pantanal warning publications, the heavy rains influenced the floods that hit the spring of the Paraguay and several tributaries subbasins in the first semester. During this period, numerous flood and emergency warnings were issued in social media and high impact media conglomerates to withdraw the cattle herd (GEOHIDRO-PANTANAL, 2015).

This exceptional scenery was intensified by the typical plain characteristics, for instance the slow water flow to the BAP discharge point (South Pantanal south) and some geo- environmental factors that could potentialize the flood specific areas influence over, for example, the relief, the soil, and the water table (ADÁMOLI, 1986).

Rain above normal was registered in the summer (March in Corumbá and January in Aquidauana), and more intensively, abnormal during May and July, contrasting the dry winter common to the region (Figure 6). This dynamic potentialized the rapid rise of Paraguay river, reaching its highest level in April, during the beginning of the flooding period (Figure 7a). Therefore, this earlier flood peak may have contributed for a longer flooding of extensive areas used for the livestock in Corumbá. In Aquidauana, the annual river behavior showed considerable differences regarding the maximum level reached during ebb and dry months (April to October), when lower levels should be expected due to the drought season. The same hydrological answer was observed during December, with the river reaching $880 \mathrm{~cm}, 80 \mathrm{~cm}$ higher than its overflow quota (DEFESA CIVIL DE AQUIDAUANA, 2017), though it reached the level of $286 \mathrm{~cm}$ in October (Figure 7b). 
a)

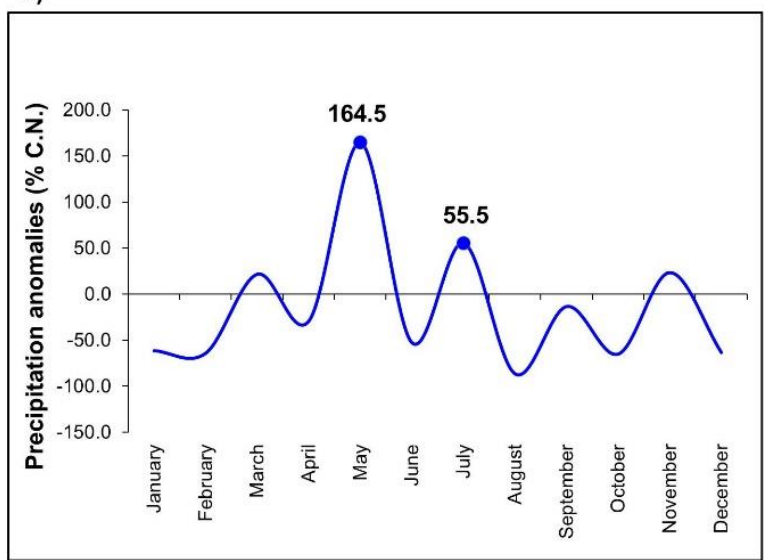

b)

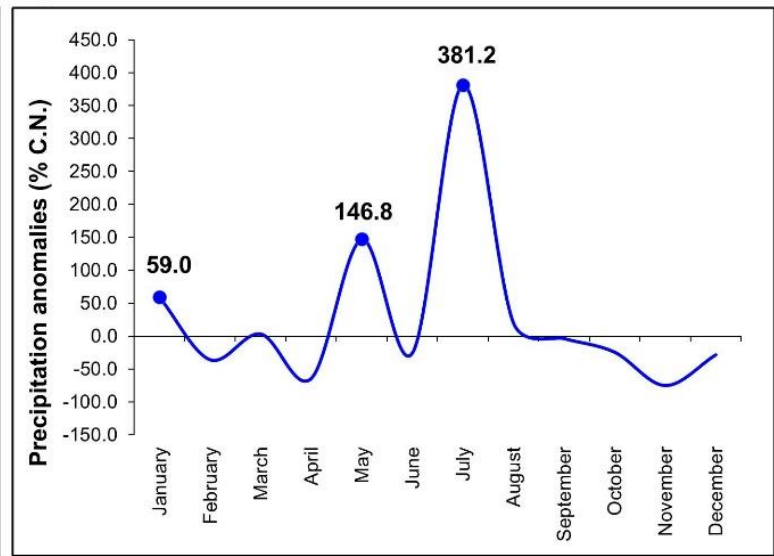

Figure 6. 2014 Precipitation anomalies (\%) in Corumbá (a) and Aquidauana (b). Souce: Adapted from Araujo (2018).

a)

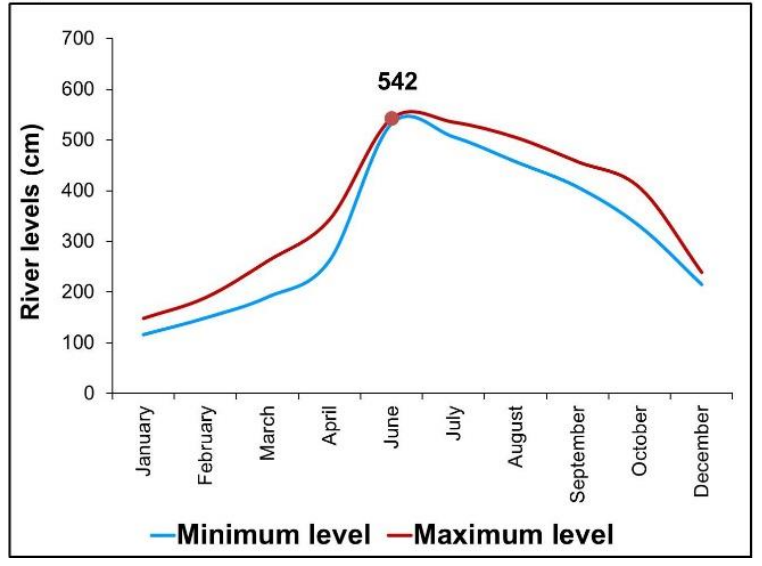

b)

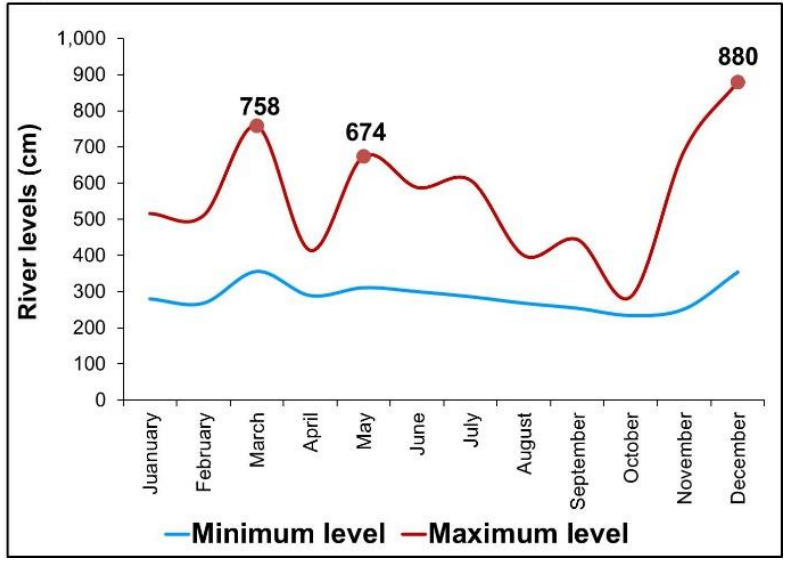

Figure 7 - 2014 level from Paraguay (cm) (a) and Aquidauana (b) rivers Source: Adapted from Araujo (2018).

While 2010 presented peaks of intensity and frequency of cattle displacement better distributed between the months (although they intensified during the drought months), 2014showed, on the other hand, a concentrated dynamic, with expressive bovine displacement during April and June in Corumbá (more than 100 thousand bovines) (Figure 8a)and June in Aquidauana (Figure 8b). 
ARAUJO, A. G. J., TEIXEIRA, D. L. S., GRILO, L. M., SILVA, L. T., OLIVEIRA, G. S., MONTEIRO, A. M. V., PARRARA, G. O., SOUZA, M. T.

\section{HYDROLOGICAL DYNAMICS AND RURAL MOBILITY: CONSIDERATIONS ON THE CATTLE TRANSIT IN THE SOUTH PANTANAL IN YEARS OF EXTREME EVENTS: THE DROUGHT OF 2010 AND THE FLOOD OF 2014}

a)

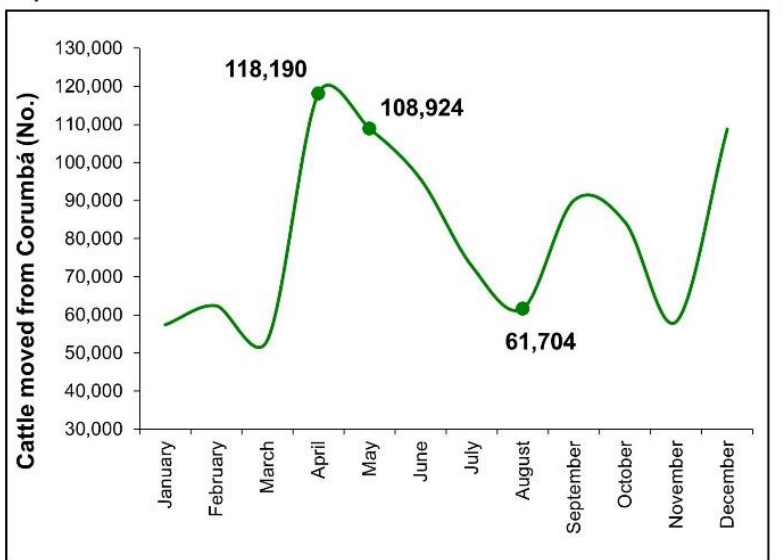

b)

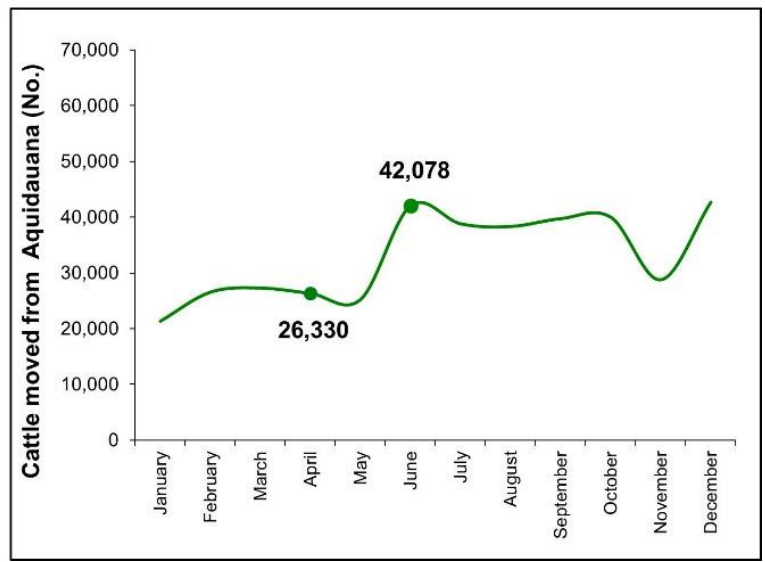

Figure 8 -Total cattle number displaced from Corumbá (a) and from Aquidauana (b) in 2014.

Source: Adapted from Araujo (2018).

The concentration of trips during April could reflect the rancher's anticipation, which moved the animal a month before the Paraguay river flood peak (May, June and July). This represents the territorial strategy of the South Pantanal ranchers, which moves the cattle in sight of eminent river overflow, preventing possible isolations and food shortages in occupied areas. This territorial logic asserts the nomadic management of the regional livestock.

Thus, it was observed in 2014 a coincidence between the sudden fluvial level elevation and the herd movement, which reflects in emergency situations and vulnerabilities at intra-regional scale, mainly Corumbá. A more profound identification of the Pantanal pace interferences and flood variabilities about the livestock production is advisable, in an effort to improve the equipment of surveillance of extreme events and identification of social economic impact.

It is important to emphasize that the market factors of the period are disregarded in this analysis, factors which can interfere in the monthly management dynamic and the outflow of beef cattle products; providing an approach solely between the environmental seasonality and the herd displacement.

\section{FINAL CONSIDERATIONS}

It was intended to establish an observation field around South Pantanal livestock production, emphasizing the cattle mobility characteristics. This survey is evaluated as the initial stage for the research, which seeks to better understand the cattle raising processes and its forms in the territory. For this, the future stages are to make a joint work with the agents that are directly involved with raising and transporting the cattle in the region, with the objective of providing a better understanding of the reasons around the cattle displacement and to develop viable actions that may assist the public authorities and productive sector in general.

The manipulation of cattle movement data in GIS has made it possible to construct a displacement network of the intra-regional landscape of the cities, considering the territorial dynamic in its wetlands and plateau areas. It was observed that the flux of bovines represents distinct levels of connectivity, highlighting the movement between both wetlands of the analyzed cities.

The network analysis was shown to be a useful tool to better capture how the territorial network articulates. The produced cartographic representation revealed logical zones (continuous) and reticular logical zones (discontinuous) of space usage. While the first 


\section{HYDROLOGICAL DYNAMICS AND RURAL MOBILITY: CONSIDERATIONS ON THE CATTLE TRANSIT IN THE SOUTH PANTANAL IN YEARS OF EXTREME EVENTS: THE DROUGHT OF 2010 AND THE FLOOD OF 2014}

logic is referred to proximity and spatial contiguity, such as ranch areas themselves or the cities political-administrative divisions, the second prioritize the network disposition and whether they relate with the flows and connections. Without dichotomizing both logics, it is about regarding the multiple forms and processes.

Furthermore, the scale question appears as a necessity to be addressed during territory political formulation for South Pantanal. The political strategies could and must be articulated prioritizing zonal dominance spaces and the issues that imply essentially reticular spaces, contingents of networks and mobility circuits.

The concern around recent harsh hydrological events has awoken the interest of verifying the livestock movement patterns in South Pantanal. The results have identified an increase in displacement during droughts, pre flooding periods and decrease during the period of flooding, as well as an intense punctual flux in 2014, suggesting an emergency situation. This patterns request further analysis and may lead to developed adapted strategies, such as previous movement to the drought period or forward due to the rise of river levels, and on the other hand, diminish risk situations for the livestock in the region.

Considering the climatic dimension and the natural hydrological seasonality variation of Pantanal in the matters of frequency and intensity, it is necessary the investment in adaptation strategies and mitigation politics for the dangers that must contemplate the fluidic characteristic of the activity during time and space.

\section{ACKNOWLEDGEMENT}

This study was funded by CAPES and its PhD scholarship given to Ana Gabriela de Jesus Araujo. We thank as well the Meteorologist Balbina M. A. Soriano for adding rainfall data, to the veterinarians Suzana C. Ortega and Roberto $S$. Bueno for the kindness and for sending data about SANIAGRO; to the Ph.D. Leonardo Bacelar, researcher of the National Surveillance and Alert of Natural Disasters Center for its support in the generation of graphs and to the Agronomic engineer Olinda B. M. de Souza, member of the Production and Tourism Secretary of the Estado do Mato Grosso do Sul for the suggestions, readings and fruitful conversations.

\section{REFERÊNCIAS}

ABREU, U. G. P.; BERGIER, I.; PAIM, F. C.; OLIVEIRA, L. O. F.; NOGUEIRA, E.; SILVA, J. C. B.; SCHIAVI, D.; SILVA JUNIOR, C. Sistema intensivo de produção na região tropical brasileira: o caso do Pantanal. Corumbá: Embrapa Pantanal, 2018. 26 p. (Documento 155).

ABREU U. G. P.; MCMANUS, C.; SANTOS, A. S. Cattleranching, conservation and transhumance in Brazilian Pantanal. Pastoralism: Research, Policyand Practice, v.1, n.1, p. 99-114, 2010.

ADÁMOLI, J. A. Dinâmica das Inundações no Pantanal. In: SIMPÓSIO SOBRE RECURSOS NATURAIS E SÓCIO-ECONÔMICOS DO PANTANAL, 1., 1986, Corumbá. Anais... Brasília: EMBRAPA, 1986. p. 51-61.

AGÊNCIA NACIONAL DE ÁGUAS - ANA. Hidroweb: sistema de informações hidrológicas. Disponível em:

<http://www2.ana.gov.br/Páginas/default.aspx>. Acesso em: 16 mai. 2018.

ARAUJO, A. G. J. Influência da variabilidade hidrometeorológica sobre as lógicas territoriais da pecuária no Pantanal, Mato Grosso do Sul, Brasil. 2018. 272 p. Dissertação (Doutorado em Ciências do Sistema Terrestre) - Instituto Nacional de Pesquisas Espaciais, São José dos Campos.

ARAUJO, A. G. J.; OBREGÓN, G.; OLIVEIRA, G. S.; MONTEIRO, A. M. V.; SILVA, L. T.; SORIANO, B.; PADOVANI, C.; RODRIGUEZ D. A.; MAKSIC, J.; SILVA, J. F. Relationships between the variability in precipitation, river levels, and beef cattle production in the Brazilian Pantanal. Wetlands Ecologyand Management, v. 26, n. 5, 2018. 

SOUTH PANTANAL IN YEARS OF EXTREME EVENTS: THE DROUGHT OF 2010 AND THE FLOOD OF 2014

ARAUJO, A. G. J.; SILVA, L. T.; MONTEIRO, A. M. V.; OLIVEIRA, G.S.; RODRIGUEZ, D. A. Os Territórios da pecuária bovina de corte no Pantanal Sul Mato-Grossense: do nomadismo dos Guaicurus a multiplicidade dos dias atuais. In: CONGRESSO INTERNACIONAL DE HISTÓRIA REGIONAL, 1., 2016, Aquidauana. Anais... AGB/ANPUH-MS, 2016, 14p.

ARAUJO, A. P. C.; BICALHO, A. M. S. M.; VARGAS, I. A. Dinâmica do espaço rural do Pantanal de Mato Grosso do Sul no processo de expansão capitalista. In: SILVA, E. A.; ALMEIDA, R. A. (Orgs.). Território e territorialidades em Mato Grosso do Sul. São Paulo: Outras Expressões, 2011. v. 1, p. 83-102.

ARAUJO, A. P. C. Pantanal, um espaço em transformação. 2006. 315 p. Dissertação (Doutorado em Geografia) - Universidade Federal do Rio de Janeiro, Rio de Janeiro.

BRASIL. Presidência da República. Decreto № $\mathbf{5 . 7 4 1}$ de $\mathbf{3 0}$ de março de 2006. Brasília: Presidência da República, 2006.

CADAVID GARCIA, E. A. Comercialização do Gado Bovino do Pantanal Mato-grossense: Município de Corumbá, MS. Corumbá: EMBRAPA-CPAP, p. 44, 1985. (Circular Técnica, 16).

CÂMARA, G.; MONTEIRO, A. M. V. Conceitos básicos em ciência da geoinformação. In: CÂMARA, G.; DAVIS, C. e MONTEIRO, A. M. V. (Eds.) Introdução à Ciência da Geoinformação. São José dos Campos, INPE, 2001, cap. 2, p. 7- 41.

CLARKE, R. T., TUCCI, C. E. M., COLLISCHONN, W. Variabilidade temporal no regime hidrológico da bacia do rio Paraguai. Revista Brasileira de RecursosHídricos, v. 8, n. 1, p. 201-211, 2003.

COLLISCHONN, W., TUCCI, C. E. M., CLARKE, R. T. Further evidence of changes in hydrological regime of the river Paraguay: part of a wider phenomenon of climate change? JournalofHydrology, v. 245, p. 218-238, 2001.

CORREIO DO ESTADO. Cheia antecipada causa morte de gado nas fazendas do Pantanal. Campo Grande, 2011. Disponível em: <http://www.correiodoestado.com.br/noticias/c heia-antecipada-causa-morte-de-gadonasfazendas-do-pantanal/103836/>. Acesso em: 18 mai. 2018.

DEFESA CIVIL DE AQUIDAUANA. Comunicação por telefone. 2017.

D'OLIVEIRA, M. C.; SOUZA, M. I. L.; CORRÊA Filho, R. A. C.; MORAIS, M. D. G.; ÍTAVO, C. C. B. F.; FRANCO, G. L. Effects of road transportation or droving on the weight and metabolism of young bulls. Tropical Animal Health and Production, v. 46, p. 1447-1453, 2014.

ECOA. Ecologia e Ação. Plano de Prevenção, Mitigação e Adaptação a Impactos de Eventos Climáticos Extremos no Pantanal. Convenio MJ/SDE/FDD no0084/2011. Flipsnack, 2014.

FARIAS, P. C. A. de. 0 ciclo hidroclimático e a produção bovina na Bacia do Alto Paraguai Mato-Grossense: quais são as relações? 2018. 44 p. Dissertação (Mestrado em Recursos Hídricos) Universidade Federal de Mato Grosso, Instituto de Ciências Exatas e da Terra, Programa de PósGraduação em Recursos Hídricos, Cuiabá. 2018.

FERNANDES, E. F. D. L.; DA ANUNCIAÇÃO, V. S. Impactos de eventos climáticos extremos e seus reflexos na cidade de Aquidauana-MS. Revista GEONORTE, v. 1, n. 4, p. 707-720, 2012.

GEOHIDRO-PANTANAL. 2015. Disponível em: <https://www.embrapa.br/geohidro-pantanal>.

Acesso em: 10 mai. 2018.

HAESBAERT, R. Limites No Espaço-Tempo: A Retomada De Um Debate. Revista Brasileira de Geografia. Rio de Janeiro: v. 61, n. 1, p. 5-20, 2016.

IAGRO. Portaria № 3.505-15, de 09 de novembro de 2015a.

IAGRO. Agência de Defesa Sanitária Animal e vegetal do Estado de Mato Grosso do Sul. Relatórios Trânsito de Bovinos do Mato Grosso do Sul 2007 a 2014. Dados fornecidos. 2015b.

INSTITUTO BRASILEIRO DE GEOGRAFIA E ESTATÍSTICA - IBGE. Pesquisa da Produção 
ARAUJO, A. G. J., TEIXEIRA, D. L. S., GRILO, L. M., SILVA, L. T., OLIVEIRA, G. S., MONTEIRO, A. M. V., PARRARA, G. O., SOUZA, M. T.

HYDROLOGICAL DYNAMICS AND RURAL MOBILITY: CONSIDERATIONS ON THE CATTLE TRANSIT IN THE SOUTH PANTANAL IN YEARS OF EXTREME EVENTS: THE DROUGHT OF 2010 AND THE FLOOD OF 2014

Pecuária Municipal (PPM). 2015. Disponível em: http://www.ibge.gov.br/home/estatistica/econo mia/agropecuaria/censoagro/default.shtm.

Acesso em: 20 mai. 2018.

INSTITUTO NACIONAL DE METEOROLOGIA INMET. Normais Climatológicas do Brasil 19611990. Brasília, p. 465, 2009. ISSN ISBN: 978-8562817-01-4.

LANG, S.; BLASCHKE, T. Análise da paisagem com SIG. Tradução Hermann Kux. São Paulo:Oficina de texto, 2009.

LIMA, I. B. T. D.; RESENDE, E. K. D.; COMASTRI FILHO, J. A. O ciclo das águas no Pantanal e a cheia de 2011, Corumbá, 2011. Disponível em: <http://ainfo.cnptia.embrapa.br/digital/bitstrea m/item/79942/1/ADM144.pdf>. Acesso em: 14 abr. 2018. (Artigo de Divulgação na Mídia, n.144)

MORAES, E. C.; PEREIRA, G.; CARDOSO, F. D. S. Avaliação da precipitação e sua influência sobre as áreas inundadas no Pantanal. In: XVI SIMPÓSIO BRASILEIRO DE SENSORIAMENTO REMOTO SBSR, 2013, Foz do Iguaçu. Anais...São José dos Campos: INPE, 2013, p. 7216-7224.

MORAES, A. S. Pecuária e conservação do Pantanal: análise econômica de alternativas sustentáveis - o dilema entre benefícios privados e sociais. 2008. 265 p. Dissertação (Doutorado em Economia) - CCSA/UFPE, Rio de Janeiro.

OLIVEIRA, L. O. F. de; ABREU, U. G. P. de; DIAS, F. R. T., FERNANDES, F. A.; NOGUEIRA, E., SILVA, J. C. B. da. Estimativa da população de bovinos no Pantanal por meio de modelos temáticos e índices tradicionais. Corumbá: Embrapa Pantanal, 2016. $11 \mathrm{p}$.

PADOVANI, C. R.; JÚNIOR, L. C.; BONAFE, P.; VETTORAZZI, C. A.; DIAS, R. A. P.; DIAS, C. T. D. S.; SHIMABUKURO, Y. E.; GIRARD, P. 2011. Sistema de Monitoramento e Alerta de Inundações e Secas no Pantanal. In: XV SIMPÓSIO BRASILEIRO DE SENSORIAMENTO REMOTO - SBSR, 2011, Curitiba. Anais... Curitiba, 2011, p. 5140-5147.
PEREIRA, A. M. M.; YULE, M. F. Quantificação da área queimada no Pantanal Sul-Mato-Grossense no período crítico de 2010. In: 5o SIMPÓSIO SULAMERICANO SOBRE CONTROLE DE INCÊNDIOS FLORESTAIS, 2011, Curitiba. Anais... Curitiba, 2011, p. 248-253.

POTT, A. Ecossistema Pantanal. In PUIGNAU, J. P. (Ed.) Utilizacion y manejo de pastizales. Montevideo, IICA-PROCISUR, 1994. p. 31-44.

ROSA, A. N.; ABREU U. G. P.; SILVA L. O. C.; NOBRE C.; GONDO A. P. R. C. V. Pecuária de corte no Pantanal Brasileiro: realidade e perspectivas futuras de melhoramento. Corumbá: Embrapa Pantanal, 2007. 26 p.

SANTOS, M. C.; DE ZEN, S.; ABREU, U. G. P.; CARVALHO, T. B.; GUARDA, G. M. A pecuária de corte no Pantanal - uma análise temporal do sistema modal de produção em Corumbá/MS. In: CONGRESSO DA SOCIEDADE BRASILEIRA DE ECONOMIA, ADMINISTRAÇÃO E SOCIOLOGIA RURAL, 53., 2015, João Pessoa. Agropecuária, meio ambiente e desenvolvimento. Anais... João Pessoal: Sober, 2015.

SANTOS, L. B. L.; LONDE, L. R.; CARVALHO, T.; MENASCHÉ, D. S.; VEGA-OLIVEROS, D. A. About interfaces between Machine Learning, Complex Networks, SurvivabilityAnalysisandDisaster Risk ReductionTowardsmathematics,

computersandenvironment: a disasters perspective. Springer-Nature. In press (to be published in 2019).

SANTOS, L. B. L.; JORGE, A. A. S., ROSSATO, M.; SANTOS, J. D.; CANDIDO, O. A.; SERON, W.; DE SANTANA C. N. (geo)graphs - Complex Networks as a shapefile of nodes and a shapefile of edges for different applications. arXivPreptint, arXiv:1711.05879, 2017.

SANTOS, L. B. L. Redes Complexas de Base Territorializada (RCBT): conceito, caracterização e seu potencial de aplicação na modelagem epidemiológica. 2014. 82 p. Tese (Doutorado em Computação Aplicada) - Instituto Nacional de Pesquisas Espaciais, São José dos Campos, 2014. 
SANTOS, S. A.; DESBIEZ, A.; CRISPIM, S. M. A.; COMASTRI Filho, J. A.; ABREU, U. G. P.; RODELA, L. G. Natural and cultivated pastures and their use by cattle. In: JUNK, W. J.; DA SILVA, C. J.; NUNES DA CUNHA, C.; WANTZEN, K. M. (Eds.) The Pantanal: Ecology, biodiversity and sustainable management of a large neotropical seasonal wetland, Sofia:Pensoft Pub, 2011. p. 127-141.

SANTOS, S. A.; ABREU, U. G. P. de; COMASTRI Filho, J. A.; CRISPIM, S. M. A.; PELLEGRIN, A. O.; TOMICH, T. R. Desafios e soluções tecnológicas para a produção sustentável de gado de corte no Pantanal. Corumbá: Embrapa Pantanal, 2008. 32 p.

SANTOS, S. A.; CRISPIM, S. M. A.; COMASTRI FILHO, J. A. Pastagens no ecossistema Pantanal: Manejo, conservação e monitoramento. In: REUNIÃO ANUAL DA SOCIEDADE BRASILEIRA DE ZOOTECNIA, 42., 2005, Goiânia. Anais... Goiânia: Sociedade Brasileira de Zootecnia, p. 23-35, 2005.

SANTOS, S. A.; PELLEGRIN, A. O.; MORAES, A. S.; BARROS, A. T. M.; COMASTRI FILHO, J. A.; SERENO, J. R. B.; SANTOS E SILVA, R. A. M.; ABREU, U.G.P. Sistema de produção 01: Sistema de Produção de Gado de Corte do Pantanal.Embrapa Pantanal. Corumbá, 2002. p.21-35.
SILVA, J. S. V. da; ABDON, M. de M. Delimitação do Pantanal brasileiro e suas sub- regiões. Revista Pesquisa Agropecuária Brasileira: Brasília, v. 33, 1998, p. 1703-1711.

SOARES, M. T. S.; SORIANO, B. M. A.; ABREU, U. G. P.; SANTOS, A. S. Monitoramento do comportamento do rio Paraguai na região de Corumbá, Pantanal Sul-Mato-Grossense, 2009/2010. Embrapa Pantanal, 2010.

SOARES, M. T. S.; SORIANO, B. M. A.; ABREU, U. G. P. D.; SANTOS, S. A.; COMASTRI FILHO, J. A. Monitoramento do Comportamento do Rio Paraguai no Pantanal Sul-Mato-Grossense em 2007. Embrapa Pantanal, Corumbá, p. 5, 2007.

TOZATO, H. C.; DUBREUIL, V.; MELLO-THÉRY, N. A. Tendências e rupturas climato-hidrológicas no sítio RAMSAR PARNA Pantanal (MT, Brasil). Revista Brasileira de Climatologia 13, 2013.

TUCCI, C.; SILVEIRA, A.; SANCHEZ, J.; Albuquerque, $F$. Flowregionalization in theupperParaguaybasin, Brazil, Hydrological SciencesJournal, v. 40, n. 4, p. 485-497, 1995.

ZENITH, J. A.; SUGAI, Y. Regionalização da Pecuária Bovina no Brasil. Embrapa Gado de Corte. Brasília: 1994. 